
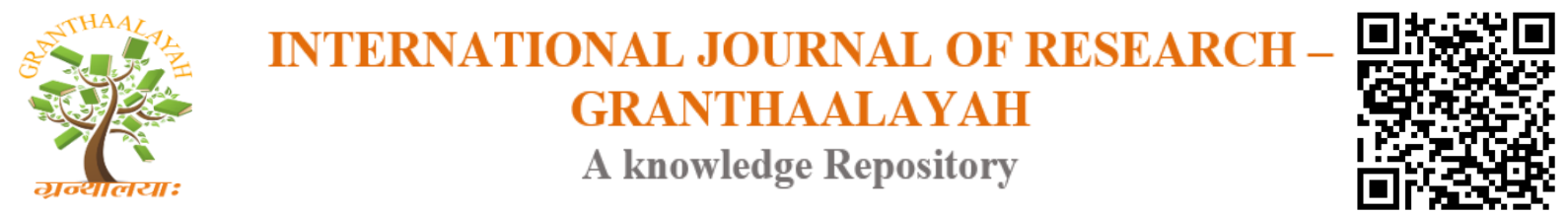

Social

\title{
A STUDY ON PROBLEMS OF ELECTED WOMEN GRAMA PANCHAYATHH MEMBERS DURING GRAMA PANCHAYATHH ELECTION IN DAKSHINA KANNADA DISTRICT
}

\author{
Ravishankar.K.R ${ }^{* 1, * 2}$ \\ ${ }^{* 1}$ Research Scholar, School of Social Work, Roshni Nilaya, Mangalore, Affiliated to Mangalore \\ University, Dakshina Kannada District, Karnataka State, India \\ ${ }^{* 2}$ Assistant Professor, MSW Department P.G. Centre, SDM College, Ujire, Belthangady, \\ Karnataka State, India
}

\begin{abstract}
The term development is no meaning without inclusion of all sections of society. Women contribute a lot to the whole society, but it is invisible. Panchayath Raj Institutions, now a day's equally (elected members) dominated by Women representation. Few important problems have been listed in tools and listed opinion of respondents whether the problem was extreame, moderate or on problem. It helped to understand, which the extreme problem, moderate is and no problem. Majority of the respondents were educated and their age was in-between 28 to 47.Political pressure and problems from political leaders have been identified as the major problems. Remaining problems were minimum. The study was focused on the problems of elected women Grama Panchayathh members during Grama Panchayathh election. The study was descriptive and mainly studied about their social, political and cultural problems. Contents of the questionnaire include respondent's age, education, marital status and the type of family. Problems during election were divided into three points. First one was no problem, second was about moderate problem and third one was extreme problem.
\end{abstract}

Keywords: Women; Panchayath; Grama Panchayathh; Participation; Election; Problem.

Cite This Article: Ravishankar.K.R. (2018). "A STUDY ON PROBLEMS OF ELECTED WOMEN GRAMA PANCHAYATHH MEMBERS DURING GRAMA PANCHAYATHH ELECTION IN DAKSHINA KANNADA DISTRICT." International Journal of Research Granthaalayah, 6(1), 36-47. https://doi.org/10.29121/granthaalayah.v6.i1.2018.1592.

\section{Introduction}

Majority of the population lives in villages. Gandhi said "unless and until villages are not developed, we cannot develop our nation". Real democracy starts in villages. Even in $21^{\text {st }}$ century we are living in highly technological era. If we neglect villages the long lasting impact will be there. 
(Jawaharlal Nehru-speech at Madurai, 15-11-1959) “Our 80\% of people live in villages. India is poor because the villages of India are poor. India will be rich if the villages are rich. Therefore the basic problem of India is to remove the poverty from the Indian villages. Some years ago we abolished the zamindari system in various parts of India, because the villages of India could not prosper under a semi-feudal system of land ownership. That is not enough. We have to go ahead further. Panchayath should be given greater power. We want the villages to have a measure of real swaraj in his/her own village. He/she should have power and not have to refer everything to big officials. We do not want the officials to interfere too much in the life of the village. We want to build swaraj right from the village up."

Women, who form nearly $50 \%$ of the total population, need to improve their capabilities to participate in various development programmes to modify their wants and make decisions or pressurize over political decisions and policies.

As the women constitute a very sizeable portion of the total population of India, their participation at grass root politics is very significant to improve the decentralized governance more successful. The struggle for participation of women in local self-governance had long lasting history.

The role of men and women in the development process has received much attention in last few decades concerns with regard to women and their inclusion or exclusion in the development process have been increasingly examined. Although the principle of equality of men and women was recognized as early as 1945 in the UN charter and in the UN declaration of human rights of 1948.

In independent india after $73^{\text {rd }}$ amendment (1992) made tremendous change in grass root level administration. Reservation to women is one of the key issue in this amendment. It is a revolutionary decision, good beginning and welcome step, having revolutionary implication.

Factors that inhibit participation are also both psychological and demographic. Psychological factors that inhibit participation are compliance with social restriction, shyness and submissiveness, lack of understanding of their role and responsibilities and weak articulation, interaction and influential skills among others. Demographic factors that inhibit participation are illiteracy, low level of education, religion and caste.

The question of women's participation in panchayath in India had merited attention of the committee on the status of women in India (1974). the national perspective plan for women (1988) had urged that political power and access to decision making authority are critical pre requisites and pleaded for women in all rural local self-governing bodies at all levels. the work participation rate of women has steadily raised from $14.22 \%$ in 1971 to $19.6 \%$ a meager $14.1 \%$ of women are employed in organized sector, but the majority find jobs in informal unorganized private sector, mainly in the low paid house hold activities (Thakur, 2010)

Most of the women who contested for election are faced lot of problems before submitting nomination, during contest and after contesting in elections. Almost all the grama pancahayath are having nearly 50 percent of elected women representatives. After the $73^{\text {rd }}$ Constitutional Amendment and in Karnataka also power has been given to weaker section of the people and 
women. The Amendment and after represents a third phase in which were empowered with autonomy and resources and visualized them as 'institutions' rather than 'units' of selfgovernment representatives in a fair way either to neglected groups of women, scheduled caste and schedules tribes (Patnaik, 2005) this has emerged as powerful instrument for social mobilizations of woman and removal of gender imbalance in lower level units of selfgovernance. Highlighting the importance of the act for the women. Manishankar Ayer (1997) observed "India is the first country in the world to adopt a grassroots approach to the conscientisation and empowerment of woman".

The woman population in India (Kurukshetra 2014) still deprived of economic, social, political rights in many types. Especially in filed at political sphere they are inadequately represented, because of gender based structural discrimination.

Singh Sisodia Yatindra, in his book, functioning of panchayat raj system, mainly focused on empowering women through panchayath raj institutions in Gujarat: some field experiences written by Chaya Patel and women in panchayath in Madhya Pradesh by Deepika Gupta. The central concern of social work discipline and profession has been to pay attention to improve the conditions of the neediest and marginal sections of the society. The objective of changing power relations in all areas of life is an extremely difficult task, especially in developing societies like India. This is an optimistic situation as the women empowerment has a prospect to raise in future from their involvement and participation in panchayat raj institutions. This experience raises our hope that the processes of women empowerment are on slow and gradual, but it is in proper direction.

Reddy Somanath, in his article empowering women in rural India: exploring the current dynamics: Kurukshethra, a journal on rural development, mainly given importance to empowerment of rural women - current dynamics. Measures to improve the status, role and participation of rural women must be given high priority. Women have fundamental right to enjoy equality with men in all aspects of life. Women can play a crucial role in and must fully participate in the sustainable development process. it is therefore essential to integrate gender perspectives in policies, projects and programmes that can be achieved by gender analysis. All plans and projects within community programmes should be assessed using the gender lens in order to achieve gender justice for women. on the other hand, reservation of seats for women in panchayath or in parliament, however, is only the first step to ensure that a certain number of women will be involved in decision-making process of the government, the very next task and challenge will be to develop their capacity so that they can perform their role probably to make a difference. expanded policy interventions with effective implementation, awareness building at family, institution and community levels and better follow up and intensified efforts for integrating gender dimensions in policy-formulation are needed to reduce constrains and to facilitate the participation of women in the mainstream of every societal affairs.

Sharma Arpita, in her article women empowerment: milestones and challenges, Kurukshethra, more importance has been given to self-decision, regarding education, mobility, economic independency, political participation, public participation and awareness to exercise rights. Empowerment is a multi-faceted, multi-dimensional and multi-layered concept. women's empowerment is a process in which women gain greater share of control over resources, 
material, human and intellectual (knowledge, information, ideas) and financial resources and control over decision-making in the home, community, society, nation and to gain power. According to a report of the government of India, "empowerment means moving from a position of enforced powerlessness to one of power". in this process, women should be empowered socially, economically, educationally and politically that can help them take self-decision regarding education, mobility, economic independency, political participation, public speaking awareness to exercise rights. Indisputably, India is committed to the cause of empowerment of women. However, the journey towards progress is long. India has witnessed great change in the last two decades. Age old prejudice and gender based biases are giving way to gender equality and harmonious development. Policies to ascend women's age of marriage, enhancing their education and opening up greater employment opportunities will also help to empower them, at least in some respects. Our goal is to cause policy, institutional and individual change that will improve the lives of women and girls everywhere.

M.Samad Abdul in his article, women empowerment and panchayati raj institutions in Kerala, Kurukshetra, said that family is willing to rise to the occasion and free from her household burden and need to facilitate her to take up the new assignment. This is a remarkable deviation from traditional outlook of our society, says the study in Kerala.

Mani Shankar Ayer, (2007) his article, a social revolution: panchyati raj, Kurukshetra, said about repeated rounds of elections to millions of panchayati raj institutions around the country constitute a democratic miracle, the baleful effects of money and muscle power. We have to be curtailed and eliminated these barriers. Here again importance has been given to democratic participation of people.

S. Sutar Aanil, in his article, the emerging women leadership: panchayats in Karnataka, social actions, has discussed on importance of democracy and efficient functioning of leaders in panchayath and how it liberated radical ideologies of their caste. The democratic and efficient functioning of women leaders in panchayath is a crucial issue that needs careful academic attention. The important observation of the study is that, the prevailing rigid caste system, cultural values and social norms surrounding the system of patriarchy have stronger implication in the good governance at the grass root level. This also pinpoints that one should bear in mind that literacy and training to women panchayat members is not sufficient to enable them to work in a democratic fashions and spirit. The emerging leadership from the lower caste is found relatively more democratic and people-centered .precisely, because of the lesser degree of patriarchy practiced among them and the more liberations and radical ideologies of their caste. The rising of more vocal and assertive leadership among the lower caste in the panchayat raj institutions makes democracy also meaningful.

Mathur Divya,(2011), in her article, women empowerment and panchayati raj: women's situation in panchayati raj, discussed about politics and said that women remain under represented in governance and politics, although no legal impediments hinder their participation in the political process. Despite the difficulties, women have made in roads to public life mainly due to the so called "male equivalence or kingship link". The exemption here is that women assess political life with the support, backing and contacts of the family, in particular that of the 
husband. In a study made in 1998, where in 15 women were surveyed, one third of the women member of parliament, for example have "family support in the background".

Noor Mohammad and Mohammad Shahid (2004), in their article, rethinking women's participation, empowerment and gender equality, a micro analysis, more discussion is about gender equality, gender justice, women's empowerment, women's participation and many more are the terms that have become watch words in the twenty first century. A century in which liberalization, privatization and globalization, the weapons of developed nations have invaded the politico-economic structure of the so called least developed, under developed and developing countries. In this era of neo-political economy with increasing marginalization, the potent victims are the weaker and vulnerable sections of society, as these groups are still not the fittest to survive in this unpleasant environment.

\section{Materials and Methods}

Decentralization of administration plays pivotal role and it facilitates citizens to participate effectively in governance. In this regard during the year 1992, 73rd Amendment Bill was passed and it was given prominence to women's participation. Generally women also constitute 50\% of the total population. But their importance in administration, political position has not been satisfying and very less importance has been given. Women's participation in politics is that, especially with governance is the necessary contemporary issue. Lot of discussion held regarding women's reservation in Panchayath Raj Institutions. Thus, the present study has made an attempt to identify with the opinion of elected women representatives of Grama Panchayath in Dakshina kannada district about problems faced them during the election Participants.

Population - Elected women members of Grama Panchayathh in Dakshina Kannada District Karnataka State. Investigator knew about total population of participants. Total numbers of taluks are five. According to the available data collected by investigator total elected women members are 1787.

Majority of the women elected members are belongs to the age group of 27 to 47.Investigator visited all the headquarters of five taluks, viz Mangalore,Putturu,Sulya,Bantwala and Belthangady and met concerned officers. With each taluk officers investigator explained about the purpose of study and shown prepared questionnaires and collected list of elected members of Grama Panchayathh.

Multistage sampling techniques adopted where in the first stage, Taluks were considered as strata and in each taluks all the panchayaths were listed and panchayaths were selected from each strata in selected panchayaths. 5 Members were included for the study, so that total sample size was 330.

The study focused on all taluks of Dakshina Kannada Distrct. Sample for the study was used Yamane and Taro (1967). As per the population 1787 (female members), 327 sample had to be selected and researcher rounded up to 330.In each taluk the following sample has been selected. 330 respondents were selected randomly from different panchayaths of five taluks. 
The scope of the study is only limited to understand the various problems faced by elected women Grama Panchayath members during Grama Panchayath election. So, the result of the study cannot be universalized to the problems faced by elected male panchayat members and also elected female member of other places of Karnataka and other states of India.

\subsection{Objective of the Study}

To know problems and prospects of elected women members during Grama Panchayath elections.

\subsection{Research Design}

The present study is based on descriptive research design. The research was carried out among elected women Grama Panchayath members. It has attempted to describe the problems faced by elected women members of Grama Panchayaths members during the election. Here it is also studied about their social, political and cultural problems,

\subsection{Tools of Data Collection}

In order to fulfill the objective of the study, the following tools were developed to gather primary data from various respondents with regard to elected female Grama Panchayath members. Questionnaires covered demographic background of the elected women Grama Panchayath members and problems faced during election.

\subsection{Methods of Data Collection}

- The primary data was collected through questionnaires.

- Procedure for primary data collection from various respondents.

- The researcher personally visited to various Grama Panchayaths and distributed questionnaires during their meeting.

\subsection{Secondary Data}

The researcher also gathered data from secondary sources with regard to problems of elected women Grama Panchayath members. The secondary data collected from annual reports, national and international journals, books newspapers, dissertations, articles and from the internet web pages.

\subsection{Data Analysis}

The data collected according to the above methodology from elected female Grama Panchayath members. The quantitative data were scrutinized, edited and classified. 


\subsection{Operational Definitions}

Problems- Problems means, struggles and inconvenience or troubles faced by elected female members of Grama Panchayaths

Elected Women Members- Elected women means, those women who have chosen by the particular ward in Grama Panchayath elections.

\subsection{Panchayat}

- A village council in India, panchayat is a kind of local government system through which social justice and local development issues are regulated and managed.

- Panchayat literally means assembly of five wise and respected elders chosen and accepted by the village community.

\section{Results and Discussions}

Table 1: Age of the Respondents

\begin{tabular}{|c|c|c|c|}
\hline Sl.No & Age & No. of respondents & Percentage \\
\hline 1 & $18-27$ years & 12 & $3.6 \%$ \\
\hline 2 & $28-37$ years & 113 & $34.2 \%$ \\
\hline 3 & $38-47$ years & 142 & 43.0 \\
\hline 4 & $48-57$ years & 51 & 15.5 \\
\hline 5 & 58 or more & 12 & 3.6 \\
\hline & Total & $\mathbf{3 3 0}$ & $\mathbf{1 0 0}$ \\
\hline
\end{tabular}

Table Number 1 depict that the age group of respondents. Here 12 (3.6\%) respondents were belongs to 18 to 27 age group. 113(34.2\%) respondents were belongs to 28 to 37age group. $142(43.0 \%)$ respondents were belongs to 38 to 47 age group. $51(15.5 \%)$ respondents belongs to 48 to 57 age group and remaining $12(3.6 \%)$ respondents were 58 and above age.

Here it is understood that 27to 47 age group respondents were more in number. They are middle aged respondents and because of local circumstances, prospect, reservation, and with their selfinterest they were contested for the election. Youngsters particularly with basic education, if they will take interest in grass root democracy then it will be positive notion.

Table 2: Education

\begin{tabular}{|c|c|c|c|}
\hline Sl.No & Education & No. of Respondents & Percentage \\
\hline 1 & Illiterate & 10 & 3.0 \\
\hline 2 & Primary education & 125 & 37.9 \\
\hline 3 & High school & 129 & 39.1 \\
\hline 4 & Pre-university & 49 & 14.8 \\
\hline 5 & Graduation & 14 & 4.2 \\
\hline 6 & Diploma & 1 & 0.3 \\
\hline 7 & Post graduation & 2 & 0.6 \\
\hline & Total & $\mathbf{3 3 0}$ & $\mathbf{1 0 0}$ \\
\hline
\end{tabular}


Table Number 2 depicts about the educational qualification of respondents. Out of 330 respondents divided it into 7 categories.10(30) respondents were illiterates, 125( 37.9\%) respondents were having primary education, 129(39.1\%) respondents were having high school education, 49(14.8\%) respondents were have degree education, $2(0.6 \%)$ were having postgraduation and $1(0.3 \%)$ is belong to diploma education.

Here it can be identified that out of 330 respondents only 10. (3.0\%) respondents were illiterates. Maximum number of respondents $254(77 \%)$ were either having primary school or high school education. The literacy rate of dakshina kannada was $88.57 \%$. Male literacy was $83.5 \%$ and female literacy was $76.05 \%$ (2011 Census).

Table 3: Marital Status

\begin{tabular}{|c|c|c|c|}
\hline Sl.No & Marital status & No. of respondents & Percentage \\
\hline 1 & Married & 313 & 94.8 \\
\hline 2 & Unmarried & 9 & 2.7 \\
\hline 3 & Widow & 8 & 2.4 \\
\hline 4 & Divorced & 0 & .0 \\
\hline & Total & $\mathbf{3 3 0}$ & $\mathbf{1 0 0}$ \\
\hline
\end{tabular}

Table no 3 shows that 313(94.8\%) respondents were married. 9(2.7\%) respondents were unmarried and remaining $8(2.4 \%)$ respondents were widows.

The maximum number of respondents belongs to 28 to 48 age groups. It is shown in table no 1 . Here it is understood that female members in villages marry in their early age.

Table 4: Type of Family

\begin{tabular}{|c|c|c|c|}
\hline SI.No & Types & No. of respondents & Percentage \\
\hline 1 & Nuclear & 238 & 72.1 \\
\hline 2 & Joint & 92 & 27.9 \\
\hline & Total & $\mathbf{3 3 0}$ & $\mathbf{1 0 0}$ \\
\hline
\end{tabular}

Table Number 4 describes that maximum respondents were belongs to nuclear family, that is $238(72.1 \%)$ and $92(27.9 \%)$ respondents were belongs to joint family.

Table 5: Problems during elections

\begin{tabular}{|c|c|c|c|}
\hline Sl.No & Problems during election & No. of respondents & Percentage \\
\hline 1 & No problem & 261 & 79.1 \\
\hline 2 & Moderate & 51 & 15.5 \\
\hline 3 & Extreme problem & 18 & 5.5 \\
\hline & Total & $\mathbf{3 3 0}$ & $\mathbf{1 0 0}$ \\
\hline
\end{tabular}

Table Number 5 depicts that 261(79.1\%) respondents opined that no problem during election, $51(15.5 \%)$ respondents were opined that moderate problems and only $18(5.5 \%)$ respondents opined that they had extreme problems. 
During election $69(21 \%)$ respondents had problem either moderate or extreme. The nature of problems faced by respondents will be shown in the table no 6 .

Table 6: Nature of problems faced by respondents during election

\begin{tabular}{|l|c|c|c|c|c|c|}
\hline \multirow{2}{*}{ Problems } & \multicolumn{2}{|c|}{ No problem } & \multicolumn{2}{c|}{ Moderate } & \multicolumn{2}{c|}{ Extreme problem } \\
\cline { 2 - 7 } & Count & Percentage & Count & Percentage & Count & Percentage \\
\hline Gender discrimination & 314 & 95.2 & 8 & 2.4 & 8 & 2.4 \\
\hline Humiliation & 308 & 93.3 & 15 & 4.5 & 7 & 2.1 \\
\hline Threat & 319 & 96.7 & 4 & 1.2 & 7 & 2.1 \\
\hline Ignorance & 295 & 89.4 & 31 & 9.4 & 4 & 1.2 \\
\hline Disobedience & 300 & 90.9 & 24 & 7.3 & 6 & 1.8 \\
\hline Caste discrimination & 314 & 95.2 & 11 & 3.3 & 5 & 1.5 \\
\hline Religious discrimination & 316 & 95.8 & 9 & 2.7 & 5 & 1.5 \\
\hline Obstruction for campaign & 314 & 95.2 & 13 & 3.9 & 3 & .9 \\
\hline Bribing & 312 & 94.5 & 15 & 4.5 & 3 & .9 \\
\hline Political pressure & 278 & 84.2 & 30 & 9.1 & 22 & 6.7 \\
\hline
\end{tabular}

Table Number 6 highlights that, nature of problems faced during Grama Panchayathh election. Gender discrimination; 314(95.2\%) respondents expressed no problem, 8 (2.4\%) respondents had moderate problems and $8(2.4 \%)$ respondents had extreme problem.

Humiliation; 308(93.3\%) respondents opined no problems, $15(4.5 \%)$ respondents had moderate problems and $7(2.1 \%)$ had extreme problem.

Threat: 319(96.7\%) respondents expressed no problem, 4 (1.2\%) respondents had moderate problems and $7(2.1 \%)$ had extreme problems.

Ignorance: $295(89.4 \%)$ respondents answered no problem, $31(9.4 \%)$ respondents had moderate and $4(1.2 \%)$ respondents had extreme problem.

Disobedience: $300(90.9 \%)$ respondents answered no problem, 24(7.3\%) respondents answered moderate and $6(1.8 \%)$ respondents had extreme problem.

Caste discrimination: $314(95.2 \%)$ respondents answered no problem about caste discrimination, $11(3.3 \%)$ respondents had moderate problem and $5(1.5 \%)$ respondents had extreme problems of caste discrimination.

Religious discrimination: 316(95.8\%) respondents had no problem, 9 (2.7\%) respondents had moderate problem and $5(1.5 \%)$ respondents had extreme problem.

Obstruction for campaign: 314(95.2\%) respondents answered that no problem, 13 (3.9\%) respondents answered that they had moderate problem and $3(1.9 \%)$ respondents had extreme problem.

Bribing: 312(94.5\%) respondents answered no problem, 15(4.5\%) respondents said that moderate problem and $3(9 \%)$ respondents answered that extreme problem. 
Political pressure: 278(84.2\%) respondents answered that no problem regarding political pressure, $30(9.1 \%)$ respondents answered that moderate problem and $22(6.7 \%)$ respondents had extreme problem.

In above mentioned table it is clear that major problems are political pressure, ignorance, Disobedience, humiliation, obstruction for campaign and bribing. When investigator had interaction with respondents majority of them expressed no problem. But comparatively political pressure is more, followed by ignorance, disobedience, humiliation and obstruction for campaign.

Table 7: Problems faced during Grama Panchayathh election from various Persons/Groups

\begin{tabular}{|l|c|c|c|c|c|c|c|c|}
\hline & \multicolumn{2}{|c|}{ No problem } & \multicolumn{2}{c|}{ Moderate } & Extreme problem & \multicolumn{2}{c|}{ Total } \\
\hline & Count & $\mathbf{\%}$ & Count & $\mathbf{\%}$ & Count & \% & Count & $\%$ \\
\hline Husband & 321 & 97.3 & 6 & 1.8 & 3 & .9 & 330 & 100 \\
\hline Brothers/sisters & 324 & 98.2 & 3 & .9 & 3 & .9 & 330 & 100 \\
\hline Family members & 323 & 97.9 & 7 & 2.1 & 0 & .0 & 330 & 100 \\
\hline Neighbors & 310 & 93.9 & 17 & 5.2 & 3 & .9 & 330 & 100 \\
\hline Relatives & 321 & 97.3 & 8 & 2.4 & 1 & .3 & 330 & 100 \\
\hline Political leaders & 306 & 92.7 & 15 & 4.5 & 9 & 2.7 & 330 & 100 \\
\hline Members of the caste & 330 & 10 & 0 & .0 & 0 & .0 & 330 & 100 \\
\hline Community leaders & 323 & 97.9 & 7 & 2.1 & 0 & .0 & 330 & 100 \\
\hline Religious leaders & 327 & 99.1 & 0 & .0 & 3 & .9 & 330 & 100 \\
\hline Children & 323 & 97.9 & 7 & 2.1 & 0 & .0 & 330 & 100 \\
\hline General public & 309 & 93.6 & 16 & 4.8 & 5 & 1.5 & 330 & 100 \\
\hline Friends & 327 & 99.1 & 0 & .0 & 3 & .9 & 330 & 100 \\
\hline
\end{tabular}

Table no 7 give a picture of problems faced by respondents during the Grama Panchayath election from various persons and groups.

Husband -Out of 330 respondents 321 didn't have problem from their husband, 6 had moderate problem and 3 had extreme problem.

Brothers/Sisters - 324 respondents didn't have problem, 3 had moderate problem and 3 had extreme problem.

Family members - 323 didn't have problem, 7 had moderate problem and no one was having extreme problems.

Neighbors -310 respondents didn't have problem, 17 had moderate problem and 3 had extreme problem.

Relatives - 321 respondents didn't have problem 8 had moderate problem and 1 had extreme problem.

Political leaders - 306 respondents didn't have problem, 15 respondents had moderate problem and 9 respondents had extreme problem. 
Members of the caste - All the 330 respondents opined that they didn't have problem.

Community leaders -323 respondents didn't have problem and 7 had moderate problem.

Religious leaders - 327 respondents didn't have problem and 3 had extreme problem.

Children - 323 respondents didn't have problem and 7 had moderate problem.

General public - 309 respondents didn't have problem, 16 had moderate problem and 5 had extreme problem.

In Dakshina Kannada district the literacy rate was $88.57 \% \%$ and women's literacy rate was $76.05 \%$.( 2011 Census). When observation made on this table the extreme problem was only from political leaders that too $9(2.7 \%)$ respondents and16 $(4.8 \%)$ respondents moderately faced problem from general public. Women in Dakshina Kannada district enjoying high power compared to other districts of Karnataka State. Most of the educational institutions have been functioning both in rural areas and also in semi urban areas. Some of the leading NonGovernment Organizations' have also working for the women empowerment and also generates awareness about the importance of decentralization and grass root administration. Selfimportance for women is high, on the other hand compared to the condition of men in the district they stay behind inferior in the hierarchy.

\section{Conclusion and Recommendations}

It is better to organize seminars and workshops in Taluk, District and in state levels mainly related to women's issues. It helps to create a platform to female members to interact with various skilled people and it facilitates them to think in better way.

Preparing and motivating female elected members to accept membership and in charge of various panchayath level committees and community development programmes, strengthens their personality and increases self-confidence and decision making power among them. Majority of respondents were belongs to 28 to 47 age group (255) in this study. This is one of the opportunities to public and also for policy makers to strengthen local self-government especially in rural areas. Mainstream of respondents were completed their primary and high school education (254) only 10 respondents were belongs to illiterate group. This is the added major strength during present day. In the fast growing contemporary society the change have also been reached to villages. This is very significant that citizens' elected representatives could take part effectively. They can raise voice, take decision and invest their ideas with policy makers. Majority of respondents were married (313) and were belongs to nuclear family (238).

Political pressure (52) and ignorance (35) were the problems faced by respondents during election. During informal discussion with women members, some said that local political party leaders have been approached them or for some pressurized through family members to contest in the election. Political parties are also no other preference because of reservation policy of government. Some had opinion that, they just go to panchayath and male members and other officials of Grama Panchayath ignore them. Now the key issue is strengthen elected women 
members. Just having education and implementing reservation will never improve active participation, this makes objective presence only. Need of hour is giving training, support from family, making male members and political parties to recognize the changing system and its importance. One of the admiring stuff is women members openly expressing their views during interaction with few respondents in front of their family members and also some in front of their husband.

\section{References}

[1] Dr.M.Abdul Samad Women Empowerment and Panchayati Raj Institutions in Kerala, Kurukshetra, Volume 55. No 5, (2007) P.P 37 to 41.

[2] Mani Shankar Aiyar, (2007) a Social Revolution: Panchyati Raj, Kurukshetra, and Volume 55. No 5, P.P 43 to 48

[3] Nandini Rai (2007) Geographies of Indian Women - A tale of contesting spaces, Social Change, Volume 37, No.3 Page 78 to 91.

[4] Indian Express Editorial (2007) Women's participation in Panchayath Raj system.

[5] Bishnu C Barik and Umesh C Sahoo (2009) Panchayat Raj Institutions and Rural Development, Rawat Publications.

[6] Dr.Sheikh Nazir Jabbar (2011) participation of SC/ST women in Politics and local barriers, Women's link, Volume 17 No.4, P.P26 to 30.

[7] M.S. Kulhani (2011) Women and our Panchayathi Raj System, Neha publishers and Distributors New Delhi.

[8] Sachidananda Satapathy, Researcher ( Project base) , ISEC , Bangalore, E mail sachisatpathy@yahoo.com, Women's Empowerment And Panchayati Raj: A Case study from Orissa ( India)

[9] Sathe D., Stephan Klasen, Jan Priebe, Mithila Biniwale (2013). "Can the female sarpanch deliver? Evidence from Maharashtra", Economic and Political Weekly, Volume XLVII (No.2) 51-56.

[10] Singh k Ajay (2002), Women's empowerment - promises and reality, Integral liberation Volume 6. No.4, P.P 251-256

\footnotetext{
*Corresponding author.

E-mail address: kr.ravishankar@ rediffmail.com
} 